\title{
Social media use of prospective teachers in the post-truth era: Confirmation, trust, critical thinking tendency
}

\author{
Burcu SEL * \\ Republic of Turkey Ministry of National Education, Ankara, Turkey. \\ ORCID: 0000-0002-7663-0434
}

\begin{tabular}{ll}
\hline \hline Article history & Critical thinking, trust and confirmation towards social media have \\
Received: & become increasingly important in this period called the post-truth era \\
& when the reality has become indistinct, is reproduced, and the truth is \\
Received in revised form: & undermined. The study aimed to examine the prospective teachers' \\
01.08 .2021 & confirmation / trust levels and critical thinking tendencies towards social \\
& media in terms of various variables. The research was conducted with the \\
Accepted: & relational survey model. The critical thinking tendency scale and social \\
19.08 .2021 & media confirmation/trust scale were used in the data collection process. \\
Key words: & In the analysis of the data, Mann Whitney U, Kruskal-Wallis test, and \\
\hline Media literacy; & Spearman Brown Rank-Order correlation coefficient were used. It was \\
Post-truth; & observed that prospective teachers' critical thinking tendency was at a \\
Social studies & good level, and their level of confirmation/trust towards social media was \\
& at a medium level. It was determined that critical thinking tendency \\
& levels did not differ by gender, but by the number of news sources \\
& followed on social media and the frequency of reading books. It was seen \\
& that their confirmation / trust level towards social media did not differ \\
depending on gender or frequency of reading books, but the level of & confirmation varied depending on the number of news sources followed \\
& on social media. Additionally, it was determined that there was a low \\
& level of positive relationship between the skill regarding critical thinking \\
& tendency and confirmation dimension. \\
\hline
\end{tabular}

\section{Introduction}

As social media becomes the main source of information about socio-political issues and current events, it is necessary to be able to recognize "the truth" rather than "the reality", which is emotionally or instinctively assured. In this context, critical thinking and media literacy are considered as important pedagogical factors for educational institutions (Ball, 2017; D'Ancona, 2017). In this context, the post-truth phenomenon that came to the fore attracted the

\footnotetext{
*Correspondency: burcusel3@gmail.com
}

\footnotetext{
${ }^{1}$ Despite the fact that "reality" and "truth" appear to be synonymous structures referring to the meaning of "truth, reality and accurate", it is known that there are philosophical and linguistic differences between these words (Isi, 2015). While "truth" is defined as the objective beings independent of the mind, "reality" is defined as the reflection of objective truth in the mind (Cevizci, 1999) hence making it more individual-bound.
} 
attention of the public in November of the same year after it was announced by the Oxford dictionary as the word of 2016 (McIntyre, 2018). The Oxford dictionary defines post-truth as a term "relating to or denoting circumstances in which objective facts are less influential in shaping public opinion than appeals to emotion and personal belief" (Oxford Dictionaries, 2021). Although the exact etymology of the concept in question is controversial, there is a general consensus that it was first used in Serbian-American writer Steve Tesich's article dated 1992 in the journal "Nation" (D'Ancona, 2017). The point to be noted here is that the predominant side in Tesich's (1992) point of view in relation to the post-truth concept is the "people". Tesich used the concept in question in order to blame the North American "people" for silently accepting the lies created by President George Bush administration in 1992 (Vogelmann, 2018) and in defining the American politics and society with a focus not on the fraud of the politicians but on the indifference of the people to the truth who chose them (Chmielewski, 2018).

In the post-truth period, rationality is threatened by emotion, diversity by nativism, and freedom by autocracy, and science is met with skepticism and sometimes open contempt (D'Ancona, 2017). The fundamental element is that emotions, beyond rationality, are more important in understanding messages (Gilchrist, 2018). With the post-truth era, in which personal thoughts and beliefs change position with facts and evidence, what people adopt as news and the nature of the news tend towards belief and emotion; in this process, the important thing is not the truth, but the fact that the person is parallel to what they want to hear (Rochlin, 2017). With the concept expressed as "verification bias", individuals have a tendency to participate in the elements that feed their opinions (Ball, 2017). Therefore, rather than the "truth", what people regard as the "truth" becomes valuable.

In the context of social media, one of the obvious signs of post truth is fake new (Gilchrist, 2018, p.16). These are fake news stories that mimic legitimate news sources and are spread intentionally (Torres, Gerhart, \& Negahban, 2018). Fake news means fabricated information that skillfully mimics the news and benefits from existing public beliefs to influence selection behavior (Waisbord, 2018). Two other concepts that draw attention as much as fake news in post-truth understanding are metaphors defined as filter bubble and echo chamber. Without the free circulation of ideas and information, the people in echo chambers only encounter what they "already" accept and believe that all of this is happening (Dubois \& Blank, 2018). "Both concepts are closely related; however, echo chamber is more on human information behavior and filter bubble more on algorithmic information filtering and results' presentation in online services" (Zimmer, Scheibe, Stock \& Stock, 2019, p.3). Echo chambers and filter balloons minimize the possibility of encountering different facts or values in a sociocultural or political sense, creating a background that does not cause any change in personal views by moving in a linear line.

\section{Confirmation / Trust in post-truth age}

The prevalence of social media has had an exponential effect on the spread of unreal things (Tsipursky, Votta \& Roose, 2018). Considering the disappearance of the source over time after a content appears on social media and the multiplier effect of the content in question, the scope of false statements may expand over time no matter by whom this statement was created (Uzunoğlu, 2017). In this respect, news-based echo rooms and coverage of current events on social media make it difficult to use mental habits and skills that involve responsible and critical inquiry (Bowell, 2017). The groups recommended through social media's "similarity-lover" algorithms are parallel to existing groups that users like; this situation causes 
the users not to encounter a group other than their own ideas and not to learn opposite ideas (Şimşek, 2018). The easy circulation of fake news in the flow with a large effect size, its uncontrollability, and its ability to give the image of "representing the general" can gradually reach serious levels.

Misleading or incomplete information or direction of individuals or societies about the truth through social media can negatively affect choices, behaviours, and beliefs. For example, it is stated that in cases such as Vietnam, Watergate or the invasion of Iraq, false statements expressed by the official authorities for years have made the society morally numb and indifferent to the truth (Keyes, 2004). "Thus, objective truth grounded in reality (legitimate and unbiased knowledge forms) matters because it informs our value systems and, consequently, our most important policies" (Ahen, 2019, p.566). In addition to the critical examination of the reality, it becomes important to question and confirm the moral values and emotional responses that are revealed with the truth.

"Restricted" environments created on social media classify individuals' thoughts and reactions and reduce the possibility of encountering different elements. In order to prevent these adversities, it is seen that confirmation and trust mechanisms regarding social media have been established recently. The confirmation mechanisms that have emerged as one of the means against fake news are non-governmental organizations based on the understanding of social responsibility and respecting the public's right to information (Karadağ \& Ayten, 2020). Some online apps and some digital tools that verify the truth and ideas offered by news organizations and universities try to respond effectively by positioning them against fake news (Pangrazio, 2018).

Support for the confirmation of the news has not only been useful for journalists, academics and news reporters but it has also become increasingly important in the post-truth world (Gilchrist, 2018). Accordingly, it is stated that independent auditors have emerged in more than 50 countries worldwide in the last decade, and there are 113 active groups, more than $90 \%$ of which have been established since 2010, and more than 50 active groups have been established since 2015 (Graves \& Cherubini, 2016). Platforms such as "SocialMention, Storyful, Politifact, Fastfact, Topsy, Sulia, TinEye, FotoForensics and Trackur" have been created to verify/confirm content on social media (Brandtzaeg, et al., 2016, p.324); similarly, in Turkey confirmation platforms such as "doğrulukpayi.com, dogrula.org., teyit.org, bilim kazani" (Kavakl1, 2019), and "fact-checking Turkey, gunun yalanlari, malumatfurus, yalansavar" (Doruk Şahin, 2018) have been established. However, it is stated that the verification or confirmation mechanisms that have emerged as an antidote to the concept of post-truth cannot have a full effect on a society that does not have a "confirmation consciousness" (Karagöz, 2018, p.704). This situation reveals the importance of critical media literacy, especially within the framework of post-truth understanding. Besides, although there are various confirmation mechanisms that claim to be objective or independent, there are also criticisms regarding the impartiality of these mechanisms, and by which groups they are financed.

\section{Critical media literacy in the post-truth age: Critical thinking tendency}

Thanks to critical media literacy, people have access to the primary tools for critical analysis of the media and this supports the formation of an effective citizenship (Kellner \& Share, 2007; Torres \& Mercado, 2006). Critical media literacy enhances the capacity to critically analyse the relationships between media and audiences, knowledge, and power, while broadening the concept of literacy to include mass communication and different forms of 
popular culture (Kellner \& Share, 2007; Garcia, Seglem \& Share, 2013). In this context, there is a need for a pedagogical understanding that not only teaches the reasoning skills and critical analysis of the reasoning of others, but also involves the values included in questioning, values such as open mindedness and truthful humility, treats individuals equally in terms of taking the views of others seriously and hearing them regardless of their social situation, enables to examine one's own beliefs and, if there is a qualified reason, to be ready to take on other beliefs easily (Bowell, 2017). On the other hand, Zembylas (2020) argues that although the pedagogical approach based on critical thinking and media literacy is important, it will not be qualified unless its emotional background based on post truth understanding is questioned. In his research, he focuses on how educators can cope with post-truth understanding and how to recognize the risks in educational processes, while emphasizing that even critical approaches can be criticized. However, considering the integration of media literacy dating back to the 1980s with formal education in Australia, England, and Canada, it is stated that the development process is not rapid. (Share, Mamikonyan \& Lopez, 2019). In Turkey, in 2006, the implementation of "Primary School Education Elective Media Literacy Curriculum" was adopted (The Radio and Television Supreme Council [RTÜK], 2016). In addition, it is observed that media literacy was included as an independent skill for the first time in the 2018 Social Studies curriculum (Ministry of Education [MEB], 2018).

Considering critical media literacy, "critical thinking tendency" is a concept as important as critical thinking skill. This tendency is seen as an important requirement, as the individual who thinks critically both knows how to think critically and has a strong tendency in this direction (Wei \& Hu, 2018). Individuals who lack the critical thinking tendency are transformed into individuals who do not care about anything, are not interested in facts, prefer not to think, do not trust the reasoning power as a way of understanding the events or solving the problems, have little self-confidence regarding their reasoning ability, are not open to new ideas, are stubborn, insensitive, insensitive about the opinions of others, biased in questioning the quality of arguments, deny their prejudices, postpone decision-making processes, and are unwilling to rethink an opinion (Facione, 2011). Critical thinking tendency is believed to be necessary to ensure that students use their critical thinking skills at school and later when they become a part of the workforce; nonetheless, very little is known about what contributes to critical thinking tendency compared to critical thinking skills, and the effects of this contribution to the academic results (Stupnisky, Renaud, Daniels, Haynes \& Perry, 2008). Looking at the literature, it is observed that critical thinking tendency has been examined based on various variables. Critical thinking tendency has been determined to have significant differences with the variables of gender (Akbulut, 2019; Ateş, 2018; Can \& Kaymakc1, 2015; Durnac1, 2019; Facione, Giancarla, Facione \& Gainen, 1995; Rudd, Baker \& Hoover, 2000; Türkmen, 2004), age (Ay \& Akgöl, 2008; Öztürk \& Ulusoy, 2008; Sung \& Eum, 2009), education level of the mother (Karal1, 2012; Türkmen, 2014; Tümkaya \& Aybek, 2008), family income level (Karal1, 2012), frequency of reading books and newspapers (Ateş, 2018; Gencel \& Candan, 2014; Polat \& Kontaş, 2018; Soğukpınar, 2017). When considered especially in terms of post-truth understanding, it can be thought that critical thinking tendency within the framework of critical media literacy is an important driving force in reaching the truth and accelerates the process.

Critical social media literacy is an important requirement for teachers, as social media channels are not impartial, but they need various tools and strategies in this context. (Nagle, 2018). The inclusion of critical media literacy in educational processes, whether it is compulsory as an education policy or not, means that both primary school teachers and prospective teachers need guidance since they undertake critical media literacy teaching and learning (Robertson \& Hughes, 2011). Moreover, critical media literacy is considered to be a component of the basic 
curriculum of teacher education as a part of the foundations of education; however, it is thought that it is a bit late for this process (Torres \& Mercado, 2006).

Democracy in the digital networked age of "fake news" and "alternative facts" requires new literacy skills and critical awareness to read, write, and use media and technology to empower civic participation and social transformation. Unfortunately, not many educators have been prepared to teach students how to think critically with and about the media and technology that engulf us (Share, Mamikonyan \& Lopez, 2019, p.1).

Accordingly, considering the curriculum implemented in Turkey, it is important to determine the current levels of primary school teachers, who are primarily responsible for teaching primary school skills such as media literacy, recognition of patterns and biases, critical thinking. In order to weaken the potential effect of fake news and reveal the truth, it is also important to provide the necessary tools for students to understand who the power factors behind media organizations are, what they are, what they are striving for, together with critical media analysis (Barton, 2019). In this respect, it is important to teach critical media literacy in a qualified way to prevent post-truth understanding.

Considering the rapidly increasing prevalence of use of social media, it is unlikely that the educational processes expected to sprout based on the truth are unaffected by the post-truth era. Considering the concepts of "critical thinking" and "confirmation / trust", which are two important components of critical media literacy, especially in this period called "post-truth age" in which the intense impact of social media is observed, in testing whether the content encountered in social media is "real" or not by teachers, it is important to pass it through a critical filter and to use evidence and confirmation mechanisms in this direction. In a period when reality is manipulated, faded, procrastinated, and reproduced by certain structures, social media confirmation / trust levels (SMCT) and critical thinking tendency (CTT) of primary school teachers about social media, which has become almost the primary source of learning, have become increasingly important. In this research, answers to the following sub-problems were sought: Concerning prospective primary school teachers,

(1) What are their SMCT and CTT levels?

(2) Do SMCT and CTT levels differ by gender?

(3) Do SMCT and CTT levels differ according to the number of news sources they follow regularly on social media?

(4) Do SMCT and CTT levels differ according to the frequency of reading books?

(5) Is there a significant relationship between SMCT and CTT levels?

\section{Methodology}

\section{Research design}

In this study, the relational survey method was used to determine the relationship between prospective teachers' SMCT and CTT levels. Unlike experimental research, manipulation of variables is out of question in relational studies (Fraenkel, Wallen, \& Hyun, 2011). In relational studies, researchers use correlational statistics to define and measure relationships or degrees between two or more variables (Creswell, 2012). In this context, the presence / absence, direction, level of the relationship between them were examined by considering various variables without any intervention in the basic variables. 


\section{Participants}

In the research, the study sample was formed by 199 prospective teachers who were studying in their last year at Gazi University Faculty of Education, Department of Classroom Education in 2020. The convenience sampling method was used to form the study group. "A convenience sample is a group of individuals who (conveniently) are available for study" (Fraenkel, Wallen \& Hyun, 2011, s.99). In this method, the researcher chooses a situation that is close and easy to access (Yıldırım \& Şimşek, 2016). Similarly, prospective teachers enrolled in a study in the close environment of the researcher were selected as the participants of this study.

\section{Research instruments and procedures}

In the research, "Critical Thinking Tendency Scale" developed by Karalı (2012) and "Social Media Confirmation / Trust Scale" developed by Çömlekçi and Başol (2019) were used as data collection tools.

The five-point Likert-type CTT scale developed by Karalı (2012) consists of 21 items and two factors. The first factor called "skill" consists of 12 items and the second factor called "value" consists of 9 items. The reliability coefficient of the scale was determined to be 0.794 . The scores to be obtained from the critical thinking tendency scale were determined as the highest level (89-105), high level (72-88), medium level (55-71), low level (38-54) and lowest level (21-37). In this study, reliability coefficient of the scale was calculated as 0.772 in first factor, 0.614 in second factor, and 0.769 in the entire scale.

The five-point Likert-type scale, developed by Çömlekçi and Başol (2019), consists of 10 items and has a three-factor structure. The factor named "confirmation" includes four items, the factor named "trust in corporate social media posts" consists of three items, and the factor named "trust in individual social media posts" includes three items. The reliability coefficients of the factors are $0.830,0.667$ and 0.651 , respectively; and for the whole scale, it was determined as 0.705 . While evaluating the scores obtained in the first, second and third factors, the average is taken. Accordingly, the highest score for each factor is calculated as 5 and the lowest score as 1. In this study, the reliability coefficients for the factors were calculated as $0.787,0.759,0.545$ and 0.701 on the entire scale.

Generally, reliability coefficients of .70 and above are considered to be sufficient (Nunally, 1978). On the other hand, Kline (1999) reported that the values below .70 could be expected due to the variety of the structures measured in psychologic structures. In this respect, the reliability coefficients calculated for both scales could be considered sufficient. The reliability coefficient calculated for the factors with low reliability may stem from the characteristics of the sampling or the number of items in the factor. Moreover, $\alpha$ is also strongly affected by the length of the scale (Streiner, 2003), and the value of $\alpha$ depends on the number of items in the scale (Cortina, 1993).

\section{Data analysis}

Data were analyzed using the SPSS22 software. Mahalanobis distance and missing values were identified for the extreme values. Expectation Maximization (EM) table was considered for identifying the missing values. It was concluded that there was no random distribution $(p>0.05)$, and the data with missing values belonging to the 6 participants were excluded from the data file. Shapiro Wilk test (Shapiro \& Wilk, 1965), histogram and Q-Q Plot charts were used for testing the normality assumptions. Kolmogorov-Smirnov (K-S) and 
Shapiro-Wilk tests are the two well-known tests used for normality (Hanusz \& Tarasinska, 2015 , p.85). Among these tests, K-S test is not preferred due to its low power of determination; therefore, Shapiro-Wilk test is preferred for evaluating normality since it can be performed both visually and on the SPSS software (Ghasemi \& Zahediasl, 2012, p.489). In addition, there have been recent conclusions demonstrating that Shapiro-Wilk Test can be administered for $\mathrm{n}<50$ (Genceli, 2007, p.325). According to the results of the Shapiro-Wilk test, it was observed that the data did not have normal distribution $(p>0.05)$. Moreover, the use of graphic methods (box charts and Q-Q plots, etc.) has become popular for completing the results of the normality tests, with an increasing range in recent years (Drezner, Turel, \& Zerom, 2010). It was observed that the data did not have normal distribution in the Q-Q Plot and histogram. Descriptive statistics were used for the first sub-problem, Mann Whitney U test was administered for the second subproblem, Kruskal-Wallis test was used in the third and fourth sub-problems, and Spearman Brown Rank-Orders correlation coefficient was used for the fifth sub-problem. In other words, in addition to normality, Mann Whitney $U$ test was used for determining whether there was a significant difference between the scores obtained from two independent variables. MannWhitney $U$ test involves the examination of the differences between the sequential positions of the scores obtained in different groups (Field, 2009). As in the Mann-Whitney test, Kruskal Wallis test is also based on the sequential data (Field, 2009). Kruskal Wallis test was used in the analysis of the third and fourth sub-problems since there were three independent groups, and the data did not have normal distribution.

\section{Results}

\section{Findings regarding prospective teachers' SMCT and CTT levels}

Prospective Teachers' SMCT and CTT levels are indicated in Table 1:

Table 1. Prospective Teachers' SMCT and CTT Levels

\begin{tabular}{|c|c|c|c|c|}
\hline \multicolumn{2}{|c|}{ Dimensions } & $N$ & $\overline{\mathrm{x}}$ & $S$ \\
\hline \multirow{3}{*}{$\begin{array}{l}\text { Critical } \\
\text { Thinking } \\
\text { Tendency }\end{array}$} & Skill & 199 & 47.206 & 5.171 \\
\hline & Value & 199 & 32.241 & 3.096 \\
\hline & Total & 199 & 80.447 & 7.822 \\
\hline \multirow{4}{*}{$\begin{array}{l}\text { Social media } \\
\text { confirmation } \\
\text { and trust }\end{array}$} & Confirmation & 199 & 13.351 & 2.248 \\
\hline & Trust in corporate social media posts & 199 & 8.939 & 1.947 \\
\hline & Trust in individual social media posts & 199 & 7.542 & 1.638 \\
\hline & Total & 199 & 29.834 & 3.915 \\
\hline
\end{tabular}

The mean scores of prospective teachers regarding their CTT were determined to be at a good level in the skill $(\overline{\mathrm{x}}=47.206)$ and value $(\overline{\mathrm{x}}=32.241)$ dimensions, and similarly at a good level in the whole scale $(\bar{x}=80.447)$.

The mean scores of prospective teachers regarding SMCT levels were found to be at a moderate level in the dimension of confirmation $(\overline{\mathrm{x}}=13.351)$ and the dimension of trust in corporate social media posts ( $\overline{\mathrm{x}}=8.939)$, and at a low level in the dimension of trust in individual social media posts $(\bar{x}=7.542)$. It is seen that the mean score obtained from the total scale was at a medium level $(\overline{\mathrm{x}}=29.834)$.

\section{SMCT and CTT levels of prospective teachers by gender}

The results of the Mann Whitney- $U$ test carried out regarding whether prospective teachers' CTT levels differ according to gender are as shown in Table 2: 
Table 2. Mann Whitney U Test Results for CTT Levels According to Gender

\begin{tabular}{lllllll}
\hline Dimensions & Gender & $N$ & Mean rank & Rank total & $U$ & $p$ \\
\hline \multirow{2}{*}{ Value } & Female & 150 & 100.50 & 15074.50 & 3600.50 & $.035^{*}$ \\
\cline { 2 - 6 } & Male & 49 & 98.48 & 4825.50 & & \\
\hline \multirow{2}{*}{ Skill } & Female & 150 & 95.09 & 14263.00 & \multirow{2}{*}{2938.00} & .831 \\
\cline { 2 - 6 } & Male & 49 & 115.04 & 5637.00 & & \multirow{2}{*}{3063} \\
\hline
\end{tabular}

$* p<0.05$

It was observed that the CTT levels of prospective teachers for the value dimension differed significantly in terms of gender in favor of females $(U=3600.50, p<0.05)$. In this context, it is seen that the mean rank scores of females were higher than males. However, when the mean of rank scores obtained both in the skill size $(U=2938.00 p>0.05)$ and those obtained from the whole scale $(U=3025.50, p>0.05)$ were examined, it was found that CTT levels did not differ significantly according to gender.

The results of the Mann Whitney-U test performed out regarding whether prospective teachers' SMCT levels differ according to gender are as shown in Table 3:

Table 3. Mann Whitney U Test Results for SMCT Levels According to Gender

\begin{tabular}{|c|c|c|c|c|c|c|}
\hline Dimensions & Gender & $n$ & Mean rank & Rank total & $U$ & $p$ \\
\hline \multirow[t]{2}{*}{ Confirmation } & Female & 150 & 98.88 & 14831.50 & \multirow[t]{2}{*}{3506.50} & \\
\hline & Male & 49 & 103.44 & 5068.50 & & .213 \\
\hline \multirow{2}{*}{$\begin{array}{l}\text { Trust in corporate social } \\
\text { media posts }\end{array}$} & Female & 150 & 98.21 & 14731.50 & \multirow{2}{*}{3406.50} & \\
\hline & Male & 49 & 105.48 & 5168.50 & & .625 \\
\hline \multirow{2}{*}{$\begin{array}{l}\text { Trust in individual social } \\
\text { media posts }\end{array}$} & Female & 150 & 97.37 & 14605.00 & \multirow[t]{2}{*}{3280.00} & \\
\hline & Male & 49 & 108.06 & 5295.00 & & .437 \\
\hline Total & Female & 150 & 97.10 & 14605.00 & 3240.50 & .250 \\
\hline
\end{tabular}

It was observed that regarding SMCT levels of prospective teachers, the mean rank scores obtained from confirmation $(U=3506.50, p>0.05)$, trust in corporate social media posts $(U=$ $3406.50, p>0.05)$, trust in individual social media posts $(U=3280.00, p>0.05)$ the whole scale $(U=3240.50, p>0.05)$ did not differ significantly by gender.

\section{SMCT and CTT levels of prospective teachers according to the number of regularly followed news sources on social media}

The results of the Kruskal Wallis test carried out as to whether prospective teachers' SMCT and CTT levels differed significantly according to the number of news sources they follow regularly on social media are as follows: 
Table 4. Kruskal Wallis Test Results for CTT Levels According to the Number of News Sources Followed on Social Media

\begin{tabular}{|c|c|c|c|c|c|c|c|}
\hline $\begin{array}{l}\text { The } \\
\text { sources }\end{array}$ & number of news & $n$ & Mean rank & sd & $\overline{\chi^{2}}$ & $p$ & $\begin{array}{l}\text { Significant } \\
\text { difference }\end{array}$ \\
\hline \multirow{4}{*}{ Value } & $1-3$ & 106 & 89.34 & \multirow{4}{*}{3} & \multirow{4}{*}{11.011} & \multirow{4}{*}{$.012^{*}$} & $1-3$ to $4-5$ \\
\hline & $4-5$ & 58 & 116.28 & & & & $1-3$ to $6-7$ \\
\hline & $6-7$ & 17 & 118.21 & & & & \\
\hline & More than 7 & 17 & 86.88 & & & & \\
\hline \multirow{4}{*}{ Skill } & $1-3$ & 106 & 84.71 & \multirow{4}{*}{3} & \multirow{4}{*}{15.420} & \multirow{4}{*}{$.001^{*}$} & $1-3$ to $4-5$ \\
\hline & $4-5$ & 58 & 117.98 & & & & $1-3$ to $6-7$ \\
\hline & $6-7$ & 17 & 116.26 & & & & \\
\hline & More than 7 & 17 & 111.91 & & & & \\
\hline \multirow{4}{*}{ Total } & $1-3$ & 106 & 86.05 & \multirow{4}{*}{3} & \multirow{4}{*}{14.579} & \multirow{4}{*}{$.002^{*}$} & $1-3$ to $4-5$ \\
\hline & $4-5$ & 58 & 119.32 & & & & $1-3$ to $6-7$ \\
\hline & $6-7$ & 17 & 117.85 & & & & \\
\hline & More than 7 & 17 & 97.41 & & & & \\
\hline
\end{tabular}

Considering the mean rank score of CTT levels of prospective teachers, in at least two groups, a significant difference was determined in the value dimension $\left(\chi_{(3)}^{2}=11.011, p<0.05\right)$, the skill dimension $\left(\chi_{(3)}^{2}=15.420, p<0.05\right)$ and in the entire scale $\left(\chi_{(3)}^{2}=14.579, p<0.05\right)$ depending on the number of news sources they regularly followed on social media. Mann Whitney-U test was used to determine which groups the difference originated from. In this context, it was seen on the whole scale that the mean rank score of those who regularly followed 4-5 news sources on social media was higher than those following 1-3, and the mean rank score of those who followed 6-7 news sources was higher than those who followed 1-3 news sources.

The results of the Kruskal Wallis Test carried out regarding whether prospective teachers' SMCT levels differ according to number of news sources are as shown in Table 5:

Table 5. Kruskal Wallis Test Results for SMCT Levels According to the Number of News Sources Followed on Social Media

\begin{tabular}{|c|c|c|c|c|c|c|c|}
\hline \multicolumn{2}{|c|}{ The number of news sources } & $n$ & Mean rank & $s d$ & $\chi^{2}$ & $p$ & Significant \\
\hline \multirow{4}{*}{ Confirmation } & $1-3$ & 106 & 82.10 & \multirow{4}{*}{3} & \multirow{4}{*}{11.284} & \multirow{4}{*}{$.010^{*}$} & \multirow{4}{*}{$\begin{array}{l}1-3 \text { to } 4-5 \\
4-5 \text { to more than } 7\end{array}$} \\
\hline & $4-5$ & 58 & 104.73 & & & & \\
\hline & $6-7$ & 17 & 96.29 & & & & \\
\hline & More than 7 & 17 & 129.47 & & & & \\
\hline \multirow{4}{*}{$\begin{array}{l}\text { Trust in } \\
\text { corporate social } \\
\text { media posts }\end{array}$} & $1-3$ & 106 & 94.81 & \multirow{4}{*}{3} & \multirow{4}{*}{5.170} & \multirow{4}{*}{. 160} & \multirow{4}{*}{ - } \\
\hline & $4-5$ & 58 & 96.55 & & & & \\
\hline & $6-7$ & 17 & 115.06 & & & & \\
\hline & More than 7 & 17 & 123.24 & & & & \\
\hline \multirow{4}{*}{$\begin{array}{l}\text { Trust in } \\
\text { individual social } \\
\text { media posts }\end{array}$} & $1-3$ & 106 & 99.67 & \multirow{4}{*}{3} & \multirow{4}{*}{0.855} & \multirow{4}{*}{.836} & \multirow{4}{*}{-} \\
\hline & $4-5$ & 58 & 103.28 & & & & \\
\hline & $6-7$ & 17 & 90.00 & & & & \\
\hline & More than 7 & 17 & 95.03 & & & & \\
\hline \multirow{4}{*}{ Total } & $1-3$ & 106 & 99.28 & \multirow{4}{*}{3} & \multirow{4}{*}{6.563} & \multirow{4}{*}{.087} & \multirow{4}{*}{ - } \\
\hline & $4-5$ & 58 & 89.97 & & & & \\
\hline & $6-7$ & 17 & 102.71 & & & & \\
\hline & More than 7 & 17 & 130.15 & & & & \\
\hline
\end{tabular}

${ }^{*} p<0.05$

Considering the mean rank scores of SMCT levels of prospective teachers, a significant difference was found between the two groups in the confirmation dimension $\left(\chi^{2}{ }_{(3)}=11.284\right.$, $p<0.05)$. Mann Whitney-U test was used to determine the groups from which the difference 
originated. In the confirmation dimension, the mean rank scores of those who regularly followed 4-5 news sources on social media were higher than those following 1-3 sources, and the mean rank scores of those who followed more than 7 news sources were higher than the mean rank scores of those who followed 4-5 news sources. On the other hand, no significant difference was found in the dimension of trust in corporate social media posts $\left(\chi^{2}(3)=5.170, p>\right.$ $0.05)$, in the dimension of trust in individual social media posts $\left(\chi_{(3)}^{2}=.855 p>0.05\right)$ and on the entire scale $\left(\chi^{2}(3)=6.563, p>0.05\right)$ depending on the number of news sources they regularly followed on social media.

\section{SMCT and CTT levels of prospective teachers according to frequency of reading books}

The results of the Kruskal Wallis test carried out regarding whether prospective teachers' SMCT and CTT levels differed significantly according to the frequency of reading books are as follows:

Table 6. Kruskal Wallis Test Results for CTT Levels According to the Frequency of Reading Books

\begin{tabular}{|c|c|c|c|c|c|c|c|}
\hline \multicolumn{2}{|c|}{ Frequency of reading books } & $n$ & Mean rank & $s d$ & $\chi^{2}$ & $p$ & Significant difference \\
\hline \multirow{3}{*}{ Value } & Very rarely & 51 & 85.80 & \multirow{3}{*}{2} & \multirow{3}{*}{5.860} & \multirow{3}{*}{.053} & \\
\hline & Often & 93 & 100.21 & & & & \\
\hline & Always & 55 & 112.81 & & & & \\
\hline \multirow[t]{3}{*}{ Skill } & Very rarely & 51 & 86.14 & \multirow{3}{*}{2} & \multirow{3}{*}{10.937} & \multirow{3}{*}{.004} & \multirow{3}{*}{$\begin{array}{l}\text { Very rarely - always } \\
\text { Often - always }\end{array}$} \\
\hline & Often & 93 & 95.20 & & & & \\
\hline & Always & 55 & 120.96 & & & & \\
\hline \multirow[t]{3}{*}{ Total } & Very rarely & 51 & 85.87 & \multirow{3}{*}{2} & \multirow{3}{*}{9.526} & \multirow{3}{*}{.009} & \multirow{3}{*}{$\begin{array}{l}\text { Very rarely - always } \\
\text { Often - always }\end{array}$} \\
\hline & Often & 93 & 96.42 & & & & \\
\hline & Always & 55 & 119.15 & & & & \\
\hline
\end{tabular}

When the mean rank scores for the CTT levels of prospective teachers were considered, no significant difference was determined in the value dimension $\left(\chi_{(2)}^{2}=5.860, p>0.05\right)$. On the other hand, when the mean rank scores were examined, a significant difference was found in the skill dimension $\left(\chi^{2}(2)=10.937, p<0.05\right)$ and on the entire scale $\left(\chi^{2}{ }_{(2)}=9.526, p<0.05\right)$ depending on the frequency of reading books. As a result of the Mann Whitney-U test carried out to determine from which binary groups the significant difference originated, the mean scores of prospective teachers who stated that they always read books in skill size and on the whole scale were higher than the scores of prospective teachers who stated that they read very rarely and those stating that they read frequently.

The results of the Kruskal Wallis Test carried out regarding whether prospective teachers' SMCT levels differ according to frequency of reading books are as shown in Table 7: 
Table 7. Kruskal Wallis Test Results for SMCT Levels According to the Frequency of Reading Books

\begin{tabular}{|c|c|c|c|c|c|c|c|}
\hline \multicolumn{2}{|c|}{ Frequency of reading books } & $n$ & Mean rank & $s d$ & $\chi^{2}$ & $p$ & Difference \\
\hline \multirow{3}{*}{ Confirmation } & Very rarely & 51 & 84.66 & \multirow{3}{*}{2} & \multirow{3}{*}{5.667} & \multirow{3}{*}{.059} & \multirow[t]{3}{*}{ 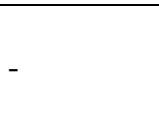 } \\
\hline & Often & 93 & 102.42 & & & & \\
\hline & Always & 55 & 110.14 & & & & \\
\hline \multirow{3}{*}{$\begin{array}{l}\text { Trust in corporate social } \\
\text { media posts }\end{array}$} & Very rarely & 51 & 94.68 & \multirow{3}{*}{2} & \multirow{3}{*}{3.340} & \multirow{3}{*}{.188} & \multirow{3}{*}{ - } \\
\hline & Often & 93 & 95.89 & & & & \\
\hline & Always & 55 & 11.88 & & & & \\
\hline \multirow{3}{*}{$\begin{array}{l}\text { Trust in individual social } \\
\text { media posts }\end{array}$} & Very rarely & 51 & 101.08 & \multirow{3}{*}{2} & \multirow{3}{*}{2.892} & \multirow{3}{*}{.235} & \multirow{3}{*}{ - } \\
\hline & Often & 93 & 105.68 & & & & \\
\hline & Always & 55 & 89.40 & & & & \\
\hline \multirow[t]{3}{*}{ Total } & Very rarely & 51 & 87.99 & \multirow{3}{*}{2} & \multirow{3}{*}{3.305} & \multirow{3}{*}{192} & \multirow{3}{*}{ - } \\
\hline & Often & 93 & 102.14 & & & & \\
\hline & Always & 55 & 107.52 & & & & \\
\hline
\end{tabular}

When the mean rank scores regarding SMCT levels of prospective teachers were considered, no significant difference was found in the dimensions of confirmation $\left(\chi_{(2)}^{2}=5.667, p>0.05\right)$, trust in corporate social media posts $\left(\chi_{(2)}^{2}=3.340, p>0.05\right)$, trust in individual social media posts $\left(\chi_{(2)}^{2}=2.892, p>0.05\right)$ and on the entire scale $\left(\chi_{(2)}^{2}=3.305, p>0.05\right)$ depending on the daily usage times of social media.

\section{Findings regarding the relationship between prospective teachers' ${ }^{S M C T}$ and CTT levels}

Findings related to Spearman Brown Rank Order correlation coefficients regarding the relationship between prospective teachers' SMCT and CTT levels are given in Table 8:

Table 8. Correlation Analysis Results of Spearman Brown Rank Order Regarding the Relationship Between CTT and SMCT Levels

\begin{tabular}{|c|c|c|c|c|c|}
\hline Sub-Dimensions & 1 & 2 & 3 & 4 & 5 \\
\hline 1. Skill Dimension (CTT) & - & $.432^{* *}$ & $.139^{*}$ & -.016 & -.041 \\
\hline 2. Value dimension (CTT) & & - & .125 & .022 & .029 \\
\hline 3. Confirmation (SCMT) & & & - & .136 & .128 \\
\hline 4. Trust in corporate social media posts (SCMT) & & & & & $.250^{* *}$ \\
\hline 5. Trust in individual social media posts (SCMT) & & & & & - \\
\hline
\end{tabular}

It is seen that there was a moderately positive relationship between skill and value dimension $(r=.432 ; p<.01)$, a weak and positive relationship between skill and confirmation dimension $(r=.139 ; p<.05)$, a weak and positive relationship between trust in corporate social media posts and trust in individual social media posts $(r=.250 ; p<.01)$.

\section{Discussion and Conclusion}

Confirmation/trust and critical thinking against fake news that gradually increase due to increased use of social media have become more and more important in the post-truth period. In this study, by using the survey model, a "perspective" was tried to be created by describing the critical thinking tendencies of prospective teachers and their confirmation/trust levels towards social media. It was observed that the prospective teachers' tendency to think critically was "at a good level". This finding of the study is in line with various studies in the literature (Akbulut, 2019; Akar, 2017; Hamurcu, Günay \& Akamca, 2005; Karal1, 2012; Öztürk, 2020). On the other hand, there are also exist other studies which show that the critical thinking 
tendencies of prospective teachers are at a moderate level (Durnac1, 2019; Kartal, 2012; Koçak et al., 2015; Şenyiğit, 2016) or at a low level low (Altıntaş, 2019; Can \& Kaymakçı, 2015; Karaman, 2016; Polat \& Kontaş, 2018). This is likely to stem from the varying sub-dimensions of the measurement tools related to the critical thinking tendency, whether the participants in different studies have taken courses on critical thinking, whether the courses in the undergraduate program serve the critical thinking tendency, or the critical thinking tendency being a complex skill. In addition, it was observed that prospective teachers' trust levels in corporate social media posts were "moderate" and their level of trust in individual social media posts was "low". In the research carried out by Sabanc1 (2018), it was observed that the users did not trust social media to a great extent; similarly, another study carried out by Çömlekçi and Başol (2019) demonstrated that trust in corporate social media posts was higher compared to trust in individual social media. However, although prospective teachers' trust in social media posts was low, it is surprising that their level of confirmation for social media was at a "moderate" level. However, one of the most important elements in the fight against post-truth understanding is the verification of the "reality" of a news shared on social media with a critical perspective, using different sources. The level of confirmation is expected to be higher when there is a concern that trust in the content encountered on social media is low and that there may be "fake news". Moreover, fake news awareness is an important predictor of perceptions of media reliability (Torres, Gerhart \& Negahban, 2018). Also, this situation may be due to the difficulty and complexity of confirmation processes in online environments.

In the present research, it is seen that prospective teachers' SMCT and CTT levels did not differ significantly by gender. This finding of the study is supported by the studies conducted by Gök \& Erdoğan (2011), Karalı (2012), Koçak et al., (2015), Korkmaz (2009), Öztürk (2020), Polat \& Kontaş (2018), and Tural \& Seçgin (2012). On the other hand, when the literature is analyzed, there are studies showing that the critical thinking tendency of females is higher than males (Akbulut, 2019; Altıntaş, 2019; Ateş, 2018; Can \& Kaymakçı, 2015; Durnac1, 2019; Facione, Giancarlo, Facione \& Gainen, 1995; Hamurcu, Günay \& Akamca, 2005; Rudd, Baker \& Hoover, 2000, Şenyiğit, 2016) or that males' critical thinking tendency is higher than females (Emir, 2012; Karaman, 2016). Since gender can be seen as a "cultural" as well as a "biological" variable, this situation may be attributed to different sociocultural factors. For example, while some sociocultural environments offer females an atmosphere of critical thinking or confirmation, some circles suppress females in this sense.

In the research, while CTT level of prospective teachers differed significantly depending on the frequency of reading books, it did not differ significantly in terms of SMCT levels. In the various studies conducted in the context of critical thinking tendency in the literature (Ateş, 2018; Polat \& Kontaş, 2018; Soğukpınar, 2017; Şenyiğit, 2016), significant differences were detected depending on the frequency of reading books. In addition, it is seen that the process of reading books can develop critical thinking skills (Murphy et al., 2014), and that there is a significant and positive relationship between critical thinking levels and attitude towards reading (Gökkus \& Delican, 2016; Koçak et al., 2015). It can be stated that book reading feeds critical thinking tendency when the common aspects of book reading processes and critical thinkers are considered such as curiosity, questioning, decision making, being open to new ideas, exploring stereotypes and prejudices, and searching for the definite. As prospective teachers' being regular readers and the development of their reading skills will also accelerate the critical thinking tendency, reading becomes important in terms of realizing fake news, cautious approach, questioning the truth, and others. It is important to encourage these skills, especially in terms of prospective teachers' being role models for their students. 
It was observed that the SMCT and CTT levels of prospective teachers differed depending on the number of news sources that they regularly followed on social media. The confirmation process on social media is unquestionably complicated due to the various sources and content methods such as content created by a large number of users, real-time information flow and video / image (Brandtzaeg et al., 2016, p.324). Therefore, questioning the reliability by using different news sources during the confirmation process is important in terms of creating evidence and distinguishing between "real" and "unreal". In reaching the "truth" through social media, the creators of the content offered to the people have responsibility as well as the people in whom the content has penetrated. If education becomes important in dealing with fake news and individuals can identify legitimate / fake news themselves, there is no need for content protection / monitoring (Barton, 2019). Therefore, the critical approach of primary school teachers to a content they encounter on social media and their confirming it through different mechanisms have an important place in the fight against post-truth understanding. However, since evaluating the credibility and reliability of resources is difficult in online environments compared to the "past", it is seen that there are important pedagogical problems as regards how to deal with fake news, and that even if critical skills can be developed, there are also concerns about how much to apply them out of the school and how many people regularly evaluate the reliability of online resources (Buckhingham, 2019). Although research on the relationship between education and the concept of post-truth is still in its infancy, especially today, when social media has become almost the primary source of learning, critically searching the truth and related values, confirming, sharing, using, questioning, criticizing in education systems have become more acute over time. In this context, there are various initiatives to integrate media literacy into teacher training in Turkey. Media literacy was included in the general culture elective courses in the classroom teaching undergraduate program by (Counsil of Higher Education [CHE], 2018). However, it was also determined that the scope of the course in question mainly included the information dimension and there were some deficiencies (Erdem, 2018). However, in the post-truth period, the need for critical approaches is increasing in teaching processes as skills such as using evidence beyond traditional media literacy, using different sources of confirmation, and having a critical thinking tendency are becoming more important in recognizing the nature and scope of fake news.

\section{Recommendations}

In this study, it can be seen as an important limitation that only prospective teachers studying in their last year were the participants of the study. In this context, in future studies, teachers in different level and branches and different variables such as income level, education level of parents etc. can also be employed. In addition, causal comparative studies on SMCT and CTT levels can be conducted. Experimental research on applications that can improve social media confirmation / trust levels and awareness can also be conducted. Although social media is becoming more and more widespread, traditional media is still important. In this direction, critical thinking and confirmation processes can be examined within the scope of traditional media.

\section{References}

Ahen, F. (2019). Futures of new post-truth: new research frontiers on disturbingly fascinating pathologies affecting information dissemination and knowledge production. Foresight. 21(5), 563-581. https://doi.org/10.1108/FS-10-2018-0088 
Akar, C. (2017). The predictive level of preservice classroom teachers' multicultural values of critical thinking disposition. Journal of Ahi Evran University Kırşehir Faculty of Education, 18(1), 741-762.

Akbulut, H. (2019). An investigation of the critical thinking dispositions of pre-service science teachers according to some variables (Master thesis). Trabzon University Graduate School of Educational Sciences, Trabzon.

Altıntaş, S. (2019). Relationship between critical thinking tendencies of social studies teacher candidates and their media literacy levels (Master thesis). Uludağ University Graduate School of Educational Sciences, Bursa.

Ateş, Y. (2018). Investigation of the tendency of social science teacher candidates to critical thinking and their characteristics of social entrepreneurship (Master thesis). Erzincan University Institute of Social Sciences Turkish and Social Sciences Education, Erzincan.

Ay, Ş., \& Akgöl, H. (2008). Eleştirel düşünme gücü ile cinsiyet, yaş ve sınıf düzeyi [Critical thinking power and gender, age and class level]. Kuramsal Eğitimbilim Dergisi, 1(2), $65-75$.

Ball, J. (2017). Post-truth. London: Biteback Publishing Limited.

Barton, C. C. (2019). Critical Literacy in the post-truth media landscape. Policy Futures in Education, 17(8), 1024-1036. https://doi.org/10.1177/1478210319831569

Bowell, T. (2017). Response to the editorial 'Education in a post-truth world'. Educational Philosophy and Theory, 49(6), 582-585. https://doi.org/10.1080/00131857.2017.1288805

Brandtzaeg, P. B., Lüders, M., Spangenberg, J., Rath-Wiggins, L., \& Følstad, A. (2016). Emerging journalistic verification practices concerning social media. Journalism Practice, 10(3), 323-342. https://doi.org/10.1080/17512786.2015.1020331

Buckingham, D. (2019). Teaching media in a 'post-truth'age: fake news, media bias and the challenge for media/digital literacy education. Culture and Education, 31(2), 213-231. https://doi.org/10.1080/11356405.2019.1603814.

Can, Ş., \& Kaymakçı, G. (2015). Pre-service teachers' critical thinking tendencies. Education Sciences, 9(6), 66-83. http://dx.doi.org/10.12739/NWSA.2015.10.2.1C0633

Cevizci, A.(1999). Paradigma felsefe sözlüğ̈̈ [Paradigm philosophy dictionary]. İstanbul: Paradigma.

Chmielewski, A. (2018). Post-truth and alethic populism. Public History Weekly, 6(34). Retrieved from https://public-history-weekly.degruyter.com/6-2018-34/post-truth-alethicpopulism/

Cortina, J. M. (1993). What is coefficient alpha? An examination of theory and applications. Journal of Applied Psychology, 78, 98-104. https://doi.org/10.1037/0021-9010.78.1.98.

Creswell, J. W. (2012). Educational research: Planning, conducting, and evaluating quantitative and qualitative research. Upper Saddle River, NJ: Merrill.

Çömlekçi, M. F., \& Başol, O. (2019). Research on social media news trust and news verification awareness. Galatasaray University Journal of Communication, 30, 55-77. https://doi.org/10.16878/gsuilet.518697

D'Ancona, M. (2017). Post-truth: The new war on truth and how to fight back. London: Ebury Press.

Doruk Şahin, Ö. (2018). Hakikat ötesi dönemde doğrulama platformları:Teyit.org örneği [Verification platforms in the post-truth era: Teyit.org sample]. The Role of Communiciation in a Transforming World International Symposium. Lefkoşa: Cyprus International University. 
Drezner, Z., Turel, O., \& Zerom, D. (2010). A modified Kolmogorov-Smirnov test for normality, Communications in Statistics-Simulation and Computation ${ }^{\circledR}, 39(4), 693-$ 704. https://doi.org/10.1080/03610911003615816

Dubois, E., \& Blank, G. (2018). The echo chamber is overstated: the moderating effect of political interest and diverse media. Information, Communication \& Society, 21(5), 729745. https://doi.org/10.1080/1369118X.2018.1428656.

Durnac1, Ü. (2019). Determination and comparison of critical and creative thinking tendencies of primary school teacher candidates (Master thesis). Giresun University Institute of Social Sciences, Giresun.

Emir, S. (2012). Eğitim fakültesi öğrencilerinin eleştirel düşünme eğilimleri [Critical thinking dispositions of faculty of education students]. Journal of Hasan Ali Yücel Faculty of Education, 9(1), 34-57.

Erdem, C. (2018, October). Yeni öğretmen yetiştirme lisans programlarının medya okuryazarlığı bağlamında değerlendirilmesi [Evaluation of new teacher training undergraduate programs in the context of media literacy]. International Congress on Politic, Economic and Social Studies. Niğde: Niğde Ömer Halisdemir University.

Gencel, İ. E. \& Candan, D. G. (2014). Investigation of critical thinking tendency and reflective thinking levels of teacher candidates. International Journal of Educational Programs and Instructional Studies, 4(8), S. 55-68.

Facione, P., Giancarlo, C., Facione, N., \& Gainen, J. (1995). The disposition toward critical thinking. Journal of General Education, 44(1), 1-25.

Facione, PA, (2011). Critical thinking: What it is and why it counts. Insight Assesment. 1-30.

Field, (2009). Discovering statistics using SPSS. London: Sage.

Fraenkel, J. R., Wallen, N. E., \& Hyun, H. H. (2011). How to design and evaluate research in education. New York: McGraw-Hill.

Garcia, A., Seglem, R., \& Share, J. (2013). Transforming teaching and learning through critical media literacy pedagogy. Learning landscapes, 6(2), 109-124. https://doi.org/10.36510/learnland.v6i2.608.

Genceli, M. (2007). Kolmogorov-smirnov, lilliefors and shaphiro-wilk tests for normality. Sigma Journal of Engineering and Natural Sciences, 25(4), 306-328.

Gilchrist, A. D. (2018). Post-truth: an outline review of the issues and what is being done to combat it. Ibersid, 12(2), 13-24.

Ghasemi, A., \& Zahediasl, S. (2012). Normality tests for statistical analysis: A guide for nonstatisticians. International Journal of Endocrinology and Metabolism, 10(2), 486-489. https://doi.org/10.5812/ijem.3505

Gök, B., \& Erdoğan, T. (2011). The investigation of the creative thinking levels and the critical thinking disposition of pre-service elementary teachers. Ankara University Journal of Educational Sciences, 44(2), 29-51. https://doi.org/10.1501/Egifak_0000001223.

Gökkuş, İ., \& Delican, B. (2016). Pre-service classroom teachers' critical thinking tendencies and attitudes towards reading habit. Cumhuriyet International Journal of Education, 5(1), 10-28. https://doi.org/10.30703/cije.321381

Graves, L., \& Cherubini, F. (2016). The rise of fact checkig sites in Europe, Reuters Institute for the Study of Journalism, University of Oxford.

Hamurcu, H., Günay, Y., \& Akamca, G. Ö. (2005). Profiles of critical thinking dispositions of science and class teacher candidates. Eurasian Journal of Educational Research, 20, 147-157.

Hanusz, Z., \& Tarasińska, J. (2015). Normalization of the Kolmogorov-Smirnov and ShapiroWilk tests of normality. Biometrical Letters, 52(2), 85-93. https://doi.org/10.1515/bile2015-0008. 
İsi, H. (2015). Philosophical and linguistic review on "gerçek" and "hakikat" words. The Journal of International Social Research, 8(41), 181-196.

Karadağ, G. H., \& Ayten, A. (2020). A comparative study of verification/fact-checking organizatons in Turkey: dogrulukpayi.com and teyit.org. Motif Academy Journal of Folklore, 13(29), 483-501. https://doi.org/10.12981/mahder.673262.

Karagöz, K. (2018). Post truth çağında yayıncılığın geleceği [The Future of Media in PostTruth Age]. TRT Academy, 3(6), 678-708.

Karal1, Y. (2012). Critical thinking disposition of students of college of education (The model of Inönü University) (Master thesis). İnönü University Institute of Educational Sciences, Malatya.

Karaman, M. K. (2016). Öğretmen adaylarının medya okuryazarlık düzeyleri ve eleştirel düşünme eğilimleri üzerine bir araştırma [A study on preservice teachers' level of media literacy and critical thinking dispositions]. Gümüşhane University Faculty of Communication Electronic Journal, 4(1), 326-350. https://doi.org/10.19145/guifd.90435.

Kartal, T. (2012). Exploring of dispositions toward critical thinking in pre-service elementary science teachers. Journal of Kirsehir Education Faculty, 13(2), 279-297.

Kavakl1, N. (2019). Dealing with fake news and internet fact-checking platforms. Journal of Erciyes Communication, 6(1), 663-682. https://doi.org/10.17680/erciyesiletisim.453398

Kellner, D., \& Share, J. (2007). Critical media literacy is not an option. Learning Inquiry, 1, 59-69. https://doi.org/10.1007/s11519-007-0004-2

Kellner, D., \& Share, J. (2007). Critical media literacy, democracy, and the reconstruction of education. In D. Macedo \& S. R. Steinberg (Eds.), Media literacy: A reader (pp. 3-23). New York, NY: Peter Lang Publishing.

Keyes, R. (2004). The post-truth era: Dishonesty and deception in contemporary life. UK: Macmillan.

Kline, P. (1999). The handbook of psychological testing. London: Routledge.

Koçak, B., Kurtlu, Y., Ulaş, H., \& Epçaçan, C. (2015). Sınıf öğretmeni adaylarının eleştirel düşünme düzeyleri ve okumaya yönelik tutumları arasındaki ilişki [Examining of the elementary class teachers' critical thinking levels and their attitudes towards reading]. Ekev Academy Journal, 61(61), 211-228.

Korkmaz, Ö. (2009). The influence of education faculties on students' critical thinking level and disposition. The Journal of Turkish Educational Sciences, 7(4), 879-902.

McIntyre, L. (2018). Post-truth. Cambridge, MA: MIT Press.

MEB (2018). Sosyal bilgiler öğretim programı [Social studies curriculum]. Retrieved from http://mufredat.meb.gov.tr/Dosyalar/201812103847686-

SOSYAL\%20B\%C4\%B0LG\%C4\%B0LER\%20\%C3\%96\%C4\%9ERET\%C4\%B0M \%20PROGRAMI\%20.pdf.

Murphy, K. P., Rowe, M. L., Ramani, G., \& Silverman, R. (2014). Promoting critical-analytic thinking in children and adolescents at home and in school. Educational Psychological Review, 26, 561-578. https://doi.org/10.1007/s10648-014-9281-3.

Nagle, J. (2018). Twitter, cyber-violence, and the need for a critical social media literacy in teacher education: A review of the literature. Teaching and Teacher Education, 76, 8694. https://doi.org/10.1016/j.tate.2018.08.014.

Nunnally, J. C. (1978). Psychometric testing. New York: McGraw-Hill.

Oxford Dictionaries (2021). Definition of post-truth. Retrieved from https://www.oxfordlearnersdictionaries.com/definition/english/posttruth?q=post+truth 
Özturk, N., \& Ulusoy, H. (2008). Baccalaureate and masters' degree nursing students' levels of critical thinking and factors influencing critical thinking. Journal of Maltepe University Nursing Science and Art, 1(1), 15-25.

Öztürk, E. (2020). Investigation of entrepreneurship characteristics and critical thinking dispositions of prospective science teachers (Master thesis). Gazi University Graduate School of Educational Sciences, Ankara.

Pangrazio, L. (2018). What's new about fake news?: Critical digital literacies in an era of fake news, post-truth and clickbait. Páginas de Educación, 11(1), 6-22. https://doi.org/10.22235/pe.v11i1.1551.

Polat, M. \& Kontaş. H. (2018). Examining primary school teachers' critical thinking disposition. Elektronic Journal of Social Sciences, 17(65), 142-159. https://doi.org/10.17755/esosder.310731

Robertson, L., \& Hughes, J. M. (2011). Investigating preservice teachers' understandings of critical media literacy. Language and Literacy, 13(2), 37-53. https://doi.org/10.20360/G22S35

Rochlin, N. (2017). Fake news: Belief in post-truth. Library Hi Tech, 35(3), 386-392. https://doi.org/10.1108/LHT-03-2017-0062

RTÜK, (2016). Türkiye'de medya okuryazarlığ1 [Media literacy in Turkey]. Retrieved from https://www.medyaokuryazarligi.gov.tr/menu_goster.php?Guid=E56CE034-6CEB-41AEA12C-B618EBEA461B\&MenuId=2.

Rudd, R., Baker, M., \& Hoover, T. (2000). Undergraduate agriculture student learning styles and critical thinking abilities: Is there a relationship? Journal of Agricultural Education, 41(3), 2-12.

Sabanc1, Y.S. (2018). Social Media Literacy: Facebook and Instagram Example. (Master thesis). Marmara University Institute of Social Sciences, İstanbul.

Shapiro, S. S., \& Wilk, M. B. (1965). An analysis of variance test for normality (Complete samples). Biometrika, 52(3/4), 591-611. https://doi.org/10.2307/2333709

Share, J., Mamikonyan, T., \& Lopez, E. (2019). Critical media literacy in teacher education, theory, and practice. In Oxford Research Encyclopedia of Education. New York, NY: Oxford University Press.

Soğukpınar, İ. (2017). Music teachers in the examination of critical thinking skills (Master thesis). Cumhuriyet University Institute of Educational Sciences, Sivas.

Streiner, D. L. (2003). Starting at the beginning: an introduction to coefficient alpha and internal consistency. Journal of Personality Assessment, 80(1), 99-103. https://doi.org/10.1207/S15327752JPA8001_18.

Stupnisky, R. H., Renaud, R. D., Daniels, L. M., Haynes, T. L., \& Perry, R. P. (2008). The interrelation of first-year college students' critical thinking disposition, perceived academic control, and academic achievement. Research in Higher Education, 49(6), 513-530. DOI 10.1007/s11162-008-9093-8

Sung, M. H., \& Eum, O. B. (2009). Relationships between critical thinking disposition, professional nursing competence and job satisfaction in clinical nurses. Journal of Korean Academy of Nursing Administration, 15(1), 26-36.

Şenyiğit, Ç. (2016). The examination of classroom teacher candidates' critical thinking positions and attitudes towards reading habit according to various variables (Master thesis). Dokuz Eylül University Institute of Educational Sciences, İzmir.

Şimşek, V. (2018). Post-truth and new medıa: a study on socıal medıa grups. Global Media Journal TR Edition, 8(16), 1-14.

Tesich, S. (1992). A government of lies. Nation, 254(1), 12-14.

Torres, R., Gerhart, N., \& Negahban, A. (2018, January). Combating fake news: An investigation of information verification behaviors on social networking sites. [Paper 
presentation]. Proceedings of the 51st Hawaii International Conference on System Sciences, Grand Hyatt, Kauai.

Torres, M., \& Mercado, M. (2006). The need for critical media literacy in teacher education core curricula. Educational Studies, 39(3), 260-282. https://doi.org/10.1207/s15326993es3903_5.

Tsipursky, G., Votta, F., \& Roose, K. M. (2018). Fighting fake news and post-truth politics with behavioral science: The pro-truth pledge. Behavior and Social Issues, 27(1), 4770. https://dx.doi.org/10.2139/ssrn.3138238.

Tural, A., \& Seçgin, F. (2012). A research about the disposition of critical thinking of the social studies and science and technology teacher candidates. E-International Journal of Education Research, 3(1), 63-77.

Tümkaya, S., \& Aybek, B. (2008). Üniversite öğrencilerinin eleştirel düşünme eğilimlerinin sosyo demografik özellikler açısından incelenmesi [An investigation of university students 'critical thinking tendencies in terms of socio-demographic properties]. Çukurova University Journal of Social Sciences Institute, 17(2), 387-402.

Türkmen, N. (2014). Comparison study of the educational sciences students in terms of their critical thinking and creativity level (Master thesis). Erciyes University Institute of Education Sciences, Kayseri.

Uzunoğlu, S. (2017). Post-truth her açıdan kullanışlı bir kavram [Post-truth is a useful concept in every aspect]. Journal of Panorama Khas, 24, 40-41.

Vogelmann, F. (2018). The problem of post-truth. rethinking the relationship between truth and politics. BEHEMOTH-A Journal on Civilisation, 11(2), 18-37. https://doi.org/10.6094/behemoth.2018.11.2.986.

Waisbord, S. (2018). Truth is what happens to news: On journalism, fake news, and post truth. $\begin{array}{lll}\text { Journalism studies, } & 19(13), & 1866-1878 .\end{array}$ https://doi.org/10.1080/1461670X.2018.1492881.

Wei, Y., \& Hu, J. (2018). A cross-sectional evaluation of EFL students' critical thinking dispositions in digital learning. Advances in Social Science, Education and Humanities Research, 195, 27-30.

Yıldırım, A., \& Şimşek, H. (2016). Sosyal bilimlerde nitel araştırma yöntemleri [Qualitative research methods in the social sciences]. Ankara: Seçkin.

Counsil of Higher Education (2018). Sınıf öğretmenliği lisans programı [Classroom teaching undergraduate program]. Retrieved from https://www.yok.gov.tr/kurumsal/idaribirimler/egitim-ogretim-dairesi/yeni-ogretmen-yetistirme-lisans-programlari.

Zembylas, M. (2020). The affective grounding of post-truth: pedagogical risks and transformative possibilities in countering post-truth claims. Pedagogy, Culture \& Society, 28(1), 77-92. https://doi.org/10.1080/14681366.2019.1598476.

Zimmer, F., Scheibe, K., Stock, M., \& Stock, W. G. (2019). Echo chambers and filter bubbles of fake news in social media. Man-made or produced by algorithms. Journal of Information Science Theory and Practice, 7(2), 40-53. 